Tema: Innovation og uddannelse

\title{
Digital kompetence som en del af lagestuderendes professionelle udvikling
}

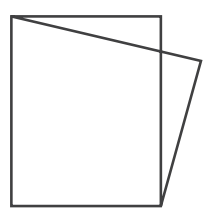

Dorthe Furstrand \& Lars Kayser, Institut for Folkesundhedsvidenskab, Det Medicinske

og Sundheds-

videnskabelige

Fakultet,

Københavns

Universitet
Udviklingen i lægegerningen og professionsrollen beskrives i snitfladen mellem samfundsmæssige behov, politiske krav og sundhedssektorens udfordringer. 'Fremtidens læger' bliver uddannet på de danske universiteter med et kompetence-sortiment, der bevæger sig ud over den biomedicinske udenadslære for at dække de nye behov. Herved bevæger uddannelsen og kravene til kompetenceudvikling sig både ud over og væk fra den traditionelle kerne i den medicinske uddannelse. Artiklen tager udgangspunkt i en aktuel uddannelsescase og sætter herigennem fokus på de udfordringer, som uddannelse af medicinstuderende til digitalt kompetente professionelle står overfor.
Med udgangspunkt i Sundhedsstyrelsens syv lægeroller og et samfundsmæssigt krav om større patientinddragelse starter vi analysen af casen ved at fokusere på, hvilken betydning disse faktorer fik for planlægningen af et kursus $i$ sundhedsinformatik for lægestuderende. Om kursusudviklingen er det en pointe, at såvel den praktiske planlægning som gennemførelsen i sig selv kan betragtes som en innovativ læringskontekst.

Caseanalysen viser her og på det uddannelsesnære niveau, hvordan inddragelsen af de digitale strategier og teknologier fordrer innovation af universitetskurset, dets undervisnings- og arbejdsformer. I et større perspektiv giver casen anledning til at rejse en uddannelses-og 
Digital kompetence som en del af lægestuderendes professionelle udvikling

fagpolitisk diskussion om, hvilken betydning den digitale udvikling, sundhedsvæsenets paradigmeskifte og lægeprofessionens egen forståelse af sin rolle har på fremtidens uddannelsesbehov.

\section{Baggrund}

Sundhedssektorens aktører og politikerne betoner ønsker og krav om, at fremtidens læger skal uddannes til at være patientens partner, kunne begå sig i den digitale verden og imødekomme de krav der stilles til ledelsesevner og organisatorisk engagement i det moderne sundhedsvæsen (Sundheds- og ældreministeriet, 2014, 2016b). Disse krav er allerede integreret i policyniveauet. Spørgsmålet er dernæst, hvordan kravene integreres, implementeres og honoreres på uddannelsesniveauet. Med udgangspunkt i implementeringsprocesser på universitetsniveau kan et institutionelt ønske om at kvalificere studerende fx gennem et "akademisk itcertifikat" identificeres. Samtidig kan der i processen iagttages, hvordan diskussion af lægens fremtidige rolle og kompetence relateres til det paradigmeskifte, der aktuelt præger sundhedssektoren. Dette paradigmeskifte orienterer sig mod patienten som partner og integrerer samtidig teknologierne. På denne baggrund er det medicinske uddannelsesniveau udfordret til også formelt at tage et teknologisk standpunkt. I den lægepolitiske og sundhedsinformatiske kontekst handler udviklingen af fagelementer dog ikke blot om anvendelse af teknologi og digital fortrolighed, men også om organisatorisk kontekst og sociale relationer. I de uddannelsesnære vendinger handler det desuden om, hvordan den uformelle ramme åbner op for et innovativt initialt ekstra-curriculært rum med mulighed for, at de studerende kan reflektere over deres professionsrolle.

I 2013 tog vi udfordringen op og udviklede et sundheds-it forløb, der i medicinsk sammenhæng var unikt. Et uddannelsestilbud, der foruden det formelle indhold vedrørende anvendelsen af it i sundhedssektoren også udviklede sig til at omfatte en diskussion om lægens roller og profession, hvilket ikke var planlagt fra institutionens side.

\section{Beskrivelse af lægens roller i et samfundsperspektiv}

For 100 år siden var lægens rolle og funktion at behandle kirurgiske og medicinske lidelser støttet af relativt simple teknologier. I dag skal lægen fungere som ekspert i et komplekst sundhedssystem, i et samarbejde med mange aktører, op imod et sygdomsspektrum, der spænder fra simple infektioner til komplekse, ofte kroniske tilstande, og altid med patienten i centrum. Det stiller nye krav til lægens kommunikative, etiske, psykologiske, organisatoriske og koordinerende kompetencer (Harden, Crosby, Davis, \& Friedman, 1999; ledema, Degeling, Braithwaite, \& Chan, 2004; Tinetti, Fried, \& Boyd, 2012). Som et svar på denne udvikling har man i Danmark siden år 2000 arbejdet med de syv lægeroller som kompetenceramme i den postgraduate speciallægeuddannelse (Sundhedsstyrelsen, 2013).

Begrebet "rolle" benyttes som beskrivelse af den adfærd og de normer, der forventes af det omgivende samfund i forbindelse med en specifik funktion. Netop samfundets behov blev overskriften, da man i Canada ville beskrive retningen for fremtidige læger i rapporten "Skills for the new millenium: report of the societal need working group" (CanMEDS 2000 Project, 1996). Her kortlægges de ønskede kompetencer og klynges i syv lægeroller, der har vist sig et robust og validt redskab; også udenfor den canadiske kontekst (Ringsted, Hansen, Davis, \& Scherpbier, 2006), og fortsat er den toneangivende kompetencemodel for lægeprofessionen. Sundhedsstyrelsen opdaterede i 2013 forståelsesrammen for de enkelte roller, inspireret både af opdateringerne til den canadiske model, såvel som de tilsvarende amerikanske og britiske modeller for lægekompetencer (Sundhedsstyrelsen, 2013). Rollernes oprindelige overskrifter blev bevaret, men opdateringen løftede forståelsen af hver enkelt rolle ind i en mikro-, meso- og makro-kontekst ved at beskrive dem på henholdsvis individ-, organisations- og samfundsniveau.

Centralt i modellen - især i den canadiske tolkning - står rollen som lœegefaglig ekspert med den faglige grundviden $\mathrm{i}$ højsædet. Lægefaglig kommunikation skal være relevant og forståelig uanset kontekst i det lægefaglige arbejde, deraf rollen som kommunikator. Rollerne som henholdsvis samarbejder og leder/ administrator/organisator anerkender behovet for, at lægen kan gå ind $\mathrm{i}$ samarbejdet i mange forskellige sammenhænge og påtage sig de nødvendige ledende og organiserende opgaver. I rollen som sundhedsfremmer skal lægen kunne arbejde med et sigte om at fremme folkesundheden, især en rolle hvor de tre niveauer har stor betydning. I et evidensbaseret sundhedsvæsen forventes lægen både at kunne forske og undervise, hvilket udtrykkes i rollen som akademiker, mens den sidste rolle, rollen som professionel i højere grad har form af en diffus meta-rolle, der understreger det behov for professionalisme $\mathrm{i}$ lægearbejdet, der er gennemgående for de seks øvrige roller. 


\section{Fremtidens læger skal uddannes til at være patientens partner, kunne begå sig i den digitale verden og imødekomme de krav der stilles til ledelsesevner og organisatorisk engagement i det moderne sundhedsvæsen.}

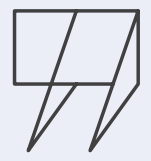

Det medicinske studium i Danmark kan beskrives som et "outcome-baseret curriculum", der tager udgangspunkt i uddannelsesbekendtgørelsen for lægestudiet (Uddannelses- og Forskningsministeriet, 2013) og tager udgangspunkt i Hardens model for, hvordan kliniske og tekniske færdigheder, personlige egenskaber samt en professionel forståelse og rolle skal tilrettelægges som en stadig og trinvis udvikling gennem lægestudiet (Harden et al., 1999).

På denne baggrund foregår løbende tilpasning og professionsudvikling $i$ et samarbejde mellem de lægefaglige organisationer og autorisationsgivende myndigheder og med input fra politikere, patientforeninger, hospitalsejere og andre aktører. De fire lægeskoler er tilsvarende i dialog med hinanden og Sundhedsstyrelsen.

Der er en tendens til, at uddannelsesinstitutionerne tager mindre del $\mathrm{i}$ diskussionen om professionsudviklingen. Dette giver indtryk af, at uddannelsesin- stitutionerne er en servicerende fremfor en professionsdefinerende instans. Dog er ansvaret for udviklingen af uddannelserne og det medicinske curriculum stadig et internt anliggende, ligesom institutionernes studienævn samt de enkelte studie- og kursusledere fortsat har fagligt råderum og mulighed for at præge uddannelsesudviklingen samt eksperimentere med undervisnings- og læringsformer. I det lys skal eksperimenter, der relaterer sig til kravet om digital kompetenceudvikling, ses. Samtidig skal eksperimenter såvel som kompetenceudviklingen ses i lyset af den lægefaglige kontekst.

\section{Digital kompetenceudvikling} og den lægefaglige kontekst I takt med at beskrivelsen af 'de syv roller' har vundet indpas, er udviklingen omkring lægearbejdet drevet af tiltagende digitalisering og af udbredelse af teknologi til patienter og pårørende. Dette forstærker kravet til læger om at være digitale kompetente aktører, ikke bare generelt, men specifikt i den lægefaglige kontekst. Det indebærer, at lægen ikke blot forstår, hvordan computeren kan understøtte dialogen med patienter og kollegaer, men også forstår de styrker og begrænsninger, der er i redskabet samt de sammenhænge, der understøtter udveksling af data.

Relationen til udviklingstræk i den lægefaglige kontekst nødvendiggør, at medicinstuderende får indsigt i de digitale og praksisnære redskaber. Men derudover, og måske vigtigere, nødvendiggør det, at de studerende får en forståelse for sundhedssektorens udfordringer i omstilling til teambaseret diagnostik, behandling og opfølgning (Sundheds- og ældreministeriet, 2016b). Der foreligger en opgave i at tænke denne udvikling ind $\mathrm{i}$ den eksisterende kompetencemodel for lægeprofessionen, ved en placering af den digitale og teknologiske kompetence i de syv lægeroller. De kan enten indgå som en del af de syv 
Digital kompetence som en del af lægestuderendes professionelle udvikling

roller i en teknologistøttet virkelighed eller udgøre en selvstændig entitet $i$ form af en ottende lægerolle. Argumentet for at bevare de syv eksisterende roller er, at den digitale og teknologiske kompetence indgår på et metaniveau i kompetencemodellen. Eksempelvis må lægen i rollen som kommunikator være i stand til at kommunikere gennem digitale kanaler, der strækker sig fra det nye face-to-face format, en videokonsultation udgør, til tekstbaseret synkron eller asynkron dialog, måske endda i en social kontekst, med de forståelsesmæssige udfordringer, der hører til her. Lægen som organisator skal kunne se sig selv i den digitale helhed sundhedsvæsnet påbyder, og den medicinske ekspert skal kunne tolke den datasky, teknologien genererer. Det digitale aspekt er til stede universelt, hvilket kunne tale for at indføre den digitale kompetence som en udvidelse af de eksisterende roller. Argumentet for at etablere en ottende rolle støttes af den amerikanske model, der blandt sine seks "kernekompetencer" inkluderer en kompetence kaldet "system-based practice", som omhandler lægens forståelse af sin rolle i forhold til den overordnede organisation og derved også griber ind i fx sammenhæng i patientforløb og patientsikkerhed (Sundhedsstyrelsen, 2013). Denne kernekompetence overlapper med lægen som sundhedsinformatiker og kunne udvides til en relevant ottende lægerolle med egen eksistensberettigelse.

Da teknologi og digitale løsninger fylder meget i lægens hverdag, er det vigtigt at finde modeller for, hvordan der kan uddannes indenfor disse områder på en måde, der er meningsfuld for de studerende og med kobling til lægens roller. Der er derfor - efter forfatternes opfattelse - et behov for at have et rum, hvor nye bud på kurser kan afprøves og analyseres som et bidrag til den kommende diskussion. Denne mulighed har vist sig i forbindelse med en proces, hvor Københavns Universitet som institution ønskede at øge de studerendes it-kompetence generelt. Analysen af vores case fra det medicinske studium starter dér på det KU-institutionelle niveau og bliver både egnet som eksempel på, hvordan den institutionelle strategi for implementering af it-kompetencer slår igennem og egnet til at belyse, hvordan universitetets interne krav står overfor de eksterne krav til den lægelige uddannelse.

\section{Fra institutionel strategi for et it-certifikat til et forløb $i$ sundhedsinformatik}

I 2006 blev der i forbindelse med den nye universitetslov og ny ledelse på Københavns Universitet nedsat et rådgivende it-udvalg. Udvalget anbefalede dels it-kombinationsuddannelser, dels at alle uddannelser fik et forløb rettet mod et såkaldt "it-certifikat", administreret af universitetets Center for IT og Innovation, CITI. Certifikatet blev planlagt til at spænde over fire kompetencekategorier; hands-on teknikker, it i faglig kontekst, it begrebskendskab samt kritisk og kreativ brug af it (Center for IT Innovation, Københavns Universitet, 2012).

I 2012 blev det besluttet at indføre certifikatet i lægeuddannelsen. It var taget i brug på studiet i 2001 med computerstøttet videodemonstration i anatomiundervisningen (Bøgeskov, Pedersen, \& Kayser, 2004) og udvidet med digitale redskaber $\mathrm{fx}$ ved laboratorieforsøg eller brug af regneark til beregningsopgaver. Trods anvendelsen af it i undervisningen fandt Thorell (et al.), at de studerende ikke havde de forventede digitale færdigheder, hvilket blev tilskrevet, at universitetet og underviserne ikke i tilstrækkelig grad inddrog it i egen praksis (Thorell, FridorffJens, Lassen, Lange, \& Kayser, 2015). It-indsatsen dækkede indtil 2012 kun det område, som af Harden betegnes de "tekniske færdigheder". Der var et behov for også at undervise i kendskab til og kritisk tilgang til de fagspecifikke it-programmer. Der blev derfor i 2012 i et bredt samarbejde mellem CITI, undervisere og studerende tilrettelagt et forløb for it-certifikatet på medicinstudiet. Det oprindelige forløb, der aldrig blev implementeret, havde alene fokus på viden om og forståelse for den hospitalsbaserede elektroniske patientjournal. Det planlagte forløb indeholdt ikke de områder, der adresserer det igangværende paradigmeskifte i form af et sammenhængende sundhedsvæsen med patientcentreret fokus og tværsektorielt samarbejde. I efteråret 2013 skete en udskiftning i undervisergruppen, og det planlagte forløb blev inden starten i 2014 revideret til at rumme de ovenfor beskrevne perspektiver. Begge forfattere deltog $i$ denne videre udvikling, og forløbet blev stærkt influeret af vores sundhedsinformatiske forståelsesramme. Undervisningens indhold blev udviklet under de tre temaer; borger, organisation og data, og med et overordnet reflekterende sigte. I forløbets introduktion møder vi de studerende, hvor de er. Gennemgange af den elektroniske patientjournals formål, opbygning og brug løftes dernæst op i den kontekst, hvor den elektroniske patientjournal og sundhedsdata fungerer organisatorisk. I så henseende afspejler kursusforløbets gennemgange bevægelsen fra mikroniveauet hos patienten og brugeren til mesoniveauet, hvor data flyder blandt sundhedsvæsnets aktører og sektorer til det makroniveau, hvor de nationale 
Tema: Innovation og uddannelse

instanser og policyniveauet inddrages $\mathrm{i}$ undervisningen.

På mikroniveauet omhandlende borgeren behandles individets evne til at tage vare på eget helbred. Fokuspunkter er den enkeltes muligheder og kompetencer, herunder digitale kompetencer. Fokuspunkter for krav til 'den kommende læge' er sikring af, at de stillede krav kan honoreres, samt at møde borgeren hvor denne er.

Med disse fokuspunkter indtager teknologien en stor plads i interaktionen mellem borgeren og den sundhedsprofessionelle. De praktiske såvel som etiske aspekter heraf behandles i undervisningen gennem begreber som sundhedskompetence, e-sundhedskompetence og empowerment samt betydningen af tværprofessionelle teams. I kølvandet herpå diskuteres muligheder ved telemedicin og brugerdrevent design.

På mesoniveauet illustreres, hvordan data kan genereres forskellige steder i sundhedssystemet og genbruges på tværs af forskellige aktører. De studerende skal kunne skabe sig overblik over datas bevægelser gennem systemet, evaluere datas relevans og validitet afhængig af kontekst og gennemskue brug af data til fx planlægnings- eller forskningsformål. Det sammenhængende patientforløb er afhængig af sammenhængende og gnidningsfri dataudveksling på mesoniveauet. På makroniveauet præsenteres de studerende for den nationale opsætning af ejerskabs- og magtstrukturer i sundhedssektorerne med henblik på forståelse og refleksion af, hvad der fremmer og hindrer professionel håndtering af sundhedsdataflow og -brug. Her lægger kurset op til en organisatorisk grundforståelse, der rummer et spektrum fra de enkelte hospitaler, afdelinger og fag- grupper, til den nationale struktur, hvor aktører som Sundhed.dk og det Fælles Medicinkort, adlyder Sundhedsdatastyrelsen og Finansministeriet. På makroniveauet inddrages også betragtninger om patientsikkerhed og kvalitetssikring.

\section{Den røde tråd}

Gennem hele udviklingsforløbet søges den røde tråd fastholdt gennem de tre temaer: individ, data og organisation. Det gennemgående princip er, at patienten/ brugeren bør være i centrum, og at de digitale løsninger i sundhedsvæsnet bør være lydhøre for individets behov og ydmyge overfor den sociale kontekst. Disse 'bør'-sætninger er normativt, men også deskriptivt rammende for de etiske implikationer, og for hvad der forventes af lægen i den lægefaglige kontekst. For undervisningen er det en del af hovedformålet, nemlig at lære de studerende at placere lægens funktion og rolle i konteksten, samt at reflektere over digitale indslag i deres kommende profession ud fra et holistisk syn der rummer faglige, kommunikative og etiske såvel som tekniske betragtninger. Kursusplanlægningen tog udgangspunkt i professionsforståelsen som givet ved de syv lægeroller og de digitale og teknologiske kompetencers placering heri. Målet var at give de studerende en forståelse af deres professions placering i forhold til den udvikling, der er sket og sker med deres fremtidige arbejdsområde.

I caseanalysen finder vi et karakteristisk mønster, hvor modningen af sundhed-it-forløbet sker gennem tre overordnede trin, der hver især bidrager til det endelige resultat. Det institutionelle ønske om et generisk it-certifikat udviklet til alle universitetsstuderende blev som første trin sat i spil overfor det Sundhedsvidenskabelige Fakultet. I det andet trin fremkommer fakultetet med ønsket om at bibringe de studerende et konkret it-kendskab i relation til deres kommende ansættelse i form af anvendelse af sundhedsvæsnets it-systemer. Gennem de første trin faciliteres processen af CITI ud fra en datalogisk forforståelse, som bidrager til, at forløbet i første omgang fokuserer på hospitalssektoren. I det tredje trin udvides forløbet til at rumme en holistisk tilgang til sundhedssektorens anvendelse af it i et paradigmeskifte. Forløbet rettes mod den lægestuderendes dannelse af professionsidentitet i en digital kontekst. Processen blev drevet ud fra undervisernes sundhedsinformatiske forforståelse og lægelige baggrund med en intention om i højere grad at klæde de studerende på til at være aktive og kritiske medspillere i det daglige kliniske arbejde i et digitaliseret sundhedsunivers. Således gik den institutionelle strategi ind $i$ en sammenhæng med et fagligt baseret standspolitisk ideal fra undervisernes side, og indførelsen af undervisningen fik for underviserne et innovativt sigte, hvor der iterativt observeres, evalueres og tilpasses i dialog med personlig læring og refleksion hos underviserne. Denne proces blev understøttet af, at kurset initialt kørte som et frivilligt tilbud i perioden 2014-2015, hvorefter forløbet blev indlejret i 2015-studieordningen på medicin som del af det nyoprettede patientsikkerhedskursus (Det Sundhedsvidenskabelige Fakultet, Københavns Universitet, 2015).

\section{Udfordringer ved uddannelsen af den digitalt kompetente læge} Lægestanden har som profession ikke i tide forstået det skift, der er ved at ske mod et patientcentreret sundhedsvæsen og et digitaliseret samfund. 


\section{Der foreligger en opgave i at tænke denne udvikling ind i den eksisterende kompetencemodel for lægeprofessionen, ved en placering af den digitale og teknologiske kompetence i de syv lægeroller.}

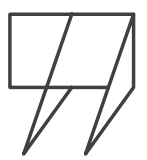

Endnu mere bagud er udviklingen i det medicinske curriculum, hvor udfordringen er, at det skal afspejle de behov og muligheder samfundet har, når lægerne står færdige som specialister 12-14 år efter påbegyndt uddannelse. Det er derfor afgørende, at universiteterne som vidensinstitutioner aktivt og på et forskningsbaseret grundlag udvikler det medicinske curriculum og tager den opgave på sig at uddanne de studerende til at blive digitalt kompetente læger, der forstår både teknologiernes muligheder og begrænsninger. Københavns Universitets ønske om at udstyre de studerende med et "akademisk it-certifikat" i 2006 har fra flere sider været mødt med kritik, da mange har ment, at digital kompetence er født ind i de generationer, der er opvokset med it. Spørgsmålet er, om de yngre studerende, der indtil nu har været betragtet som digitalt indfødte (Prensky, 2001), slet ikke er så digitalt kompetente, når det drejer sig om at forstå teknologi i en professionskontekst (Thorell et al.,
2015) og derfor har behov for at blive ført ind $\mathrm{i}$ det sundhedsinformatiske univers, som ikke blot handler om tekniske færdigheder, men også om kontekst og organisation på et mikro-, meso- og makroniveau.

Hermed bør et uddannelsesforløb i sundheds-it dække både den professionelle kontekst med inddragelse af akademiske tekster og en specifik introduktion til de eksisterende systemers funktionalitet $\mathrm{i}$ klinikken. Sidstnævnte har hidtil været forsøgt løst med et onlinekursus på universitets læringsplatform, da hospitalerne ikke har kunnet levere læringsmiljøer som intenderet. Denne opgave vil fra sommeren 2016 blive overtaget af hospitalernes læringsenheder i et samarbejde med de kliniske undervisere. Det er derfor usikkert, hvorvidt universitetet bevarer opgaven med at kvalitetssikre de studerendes digitale kompetencer i klinikken. Casen illustrerer her den uklarhed, der kan være omkring, hvor ansvaret for læring placeres mellem universitet og klinik, sådan som Sand Nielsen og Kramer også iagttager det, som beskrevet andetsteds i dette nummer (Sand Nielsen \& Kramer, n.d.).

\section{Når undervisningen tager del $\mathrm{i}$ et paradigmeskifte}

Når det pågående paradigmeskifte inddrages i undervisningen, tager undervisningen i sig selv del i paradigmeskiftet. At kultivere studerende, der er opdraget i konserverende system, til at tænke et anderledes paradigme ind $i$ deres professionelle selvforståelse er en udfordring. Udfordringen genkendes på tværs af projekter. Fx beskriver Kolbæk om sygeplejestudiets inddragelse af it (Kolbæk, n.d.), hvordan teknologien opleves som kold og maskuliniserende. Hermed skabes en afstand til ibrugtagen af denne både som pædagogisk og klinisk arbejdsredskab, da det opleves som i konflikt med de studerendes og undervisernes professionelle selvforståelse som formidlere af et varmt og 
Tema: Innovation og uddannelse

omsorgsbaseret fag. Sand Nielsen og Kramer skildrer samme dynamik i deres beretning om projekt InterTværs - en tværfaglig læringsplatform, hvor sundhedsstuderende fra en række sundhedsuddannelser mødes for at lære at skabe sammenhængende patientforløb på tværs af sektorgrænser (Sand Nielsen \& Kramer, n.d.). De oplever en forskydning mod hospitalerne, der forankrer læringen i det konservative kliniske udgangspunkt og besværliggør projektets ønske om at navigere i sektorernes snitflader.

På tværs af vore tre projekter ses en anerkendelse blandt professionelle omkring behovet for at udfordre de eksisterende paradigmer. På den anden side findes hos de studerende et tilhørsforhold i de etablerede systemer, som kan være en barriere for udviklingen. Skal der være håb for, at fremtidens sundhedsprofessionelle indlejrer denne tankegang i deres professionsidentitetsdannelse, må arbejdet løftes ind i en relevant kontekst og derved fremme en situationel læringsmulighed, $\mathrm{fx}$ ved at inddrage flere praksisnære aktiviteter. Vi oplevede hos de lægestuderende, der allerede havde været i et par kliniske ophold, en langt større evne til at kontekstualisere og perspektivere den i dette kursus tilbudte læring i forhold til de af vores studerende, der endnu ikke havde haft klinisk arbejde mellem hænderne. Kontekstuel læring med en bevidstgørelse omkring et tilbudt alternativ til det etablerede $\mathrm{i}$ deres professionelle identitetsdannelse må derfor fremmes aktivt.

\section{Udfordringen fremover}

Casen og caseanalysen viser først og fremmest, at teknologiundervisning ikke kan stå alene, men kalder på en kontekstualisering både i forhold til sundhedsvæsenets brugere og organisation. Casen demonstrerer denne kontekstualisering som et institutionelt og formelt forløb, der starter med et teknologisk udgangspunkt, men dernæst bliver sat ind i en lægepolitisk og sundhedsprofessionel kontekst. Herigennem udvikles et fagelement som informatik, der ikke blot handler om anvendelse af teknologi og digital kompetence, men også om kontekst og lægens sociale relationer til borgere, patienter, pårørende og deres sundhedsprofessionelle kollegaer. De oprindelige intentioner har herigennem udviklet sig til et fortløbende professionsrefleksivt arbejde med udforskning af, hvordan it fungerer i den sundhedssektor, der i disse år udvikler sig med sigte på inddragelse af patienter, sammenhængende patientforløb og styrket indsats overfor kronikere og ældre (Sundheds- og ældreministeriet, 2016a). 
Digital kompetence som en del af lægestuderendes professionelle udvikling

\section{REFERENCER}

Bøgeskov, M. B., Pedersen, T. H., \& Kayser, L. (2004). Brugen af en internetbaseret billeddatabase ved cellebiologikurset på medicinstudiet, Københavns Universitet. Ugeskrift for Lœger. Retrieved from http://www.forskningsdatabasen.dk/en/cata$\log / 2192889793$

CanMEDS 2000 Project. (1996). Skills for the New Millennium: Report of the Societal Needs Working Group. Royal College of Physicians and Surgeons of Canada.

Center for IT Innovation, Københavns Universitet. (2012, November 12). IT-certifikat: Medicin. Retrieved 18 May 2016, from http:// citi.ku.dk/it-certifikater/medicin/

Det Sundhedsvidenskabelige Fakultet, Københanvs Universitet. (2015). 2015-studieordning for kandidatuddannelsen i medicin ved Det Sundhedsvidenskabelige Fakultet på Københavns Universitet, School of Medical Sciences. Retrieved from http:// sund.ku.dk/uddannelse/vejledning-information/studieordninger/medicin/Medicin-ka-2015_pr._01-09-2016.pdf

Harden, R., Crosby, J., Davis, M., \& Friedman, M. (1999). AMEE Guide No. 14: Outcome-based education: Part 5-From competency to meta-competency: a model for the specification of learning outcomes. Medical Teacher, 21(6), 546-552. http://doi. org/10.1080/01421599978951

ledema, R. A., Degeling, P. J., Braithwaite, J., \& Chan, D. K. (2004). Medical Education and Curriculum Reform: Putting Reform Proposals in Context. Medical Education Online: An Electronic Journal, 2004(9), 1-11.

Kolbæk, R. (n.d.). IT-innovationer fra kontorlandskaber til læringslandskaber. Tidsskrift for Professionsstudier, nr. 23, 2016, In Press.

Prensky, M. (2001). Digital Natives, Digital Immigrants Part 1. On the Horizon, 9(5), 1-6. http://doi.org/10.1108/10748120110424816
Ringsted, C., Hansen, T. L., Davis, D., \& Scherpbier, A. (2006). Are some of the challenging aspects of the CanMEDS roles valid outside Canada? Medical Education, 40(8), 807-815. http://doi. org/10.1111/j.1365-2929.2006.02525.x

Sand Nielsen, C., \& Kramer, Ti. (n.d.). InterTværs som platform for interprofessionel uddannelsesudvikling. Tidsskrift for Professionsstudier, nr. 23, 2016, In Press.

Sundheds- og ældreministeriet. (2014). Jo før, jo bedre: tidlig diagnose, bedre behandling og flere gode leveår for alle.

Sundheds- og ældreministeriet. (2016a). Aftale om nationale mål for sundhedsvcesenet - 2016. Retrieved from http://sum.dk/ Aktuelt/Publikationer/ /media/Filer\%20-\%20Publikationer_i_ pdf/2016/Nationale-maal/Aftaletekst-paa-nationale-maal-2016. ashx

Sundheds- og ældreministeriet. (2016b). Digital understøttelse af tvœrgående komplekse patientforløb.

Sundhedsstyrelsen. (2013). De syv lœgeroller. Kbh.

Thorell, M., Fridorff-Jens, P. K., Lassen, P., Lange, T., \& Kayser, L. (2015). Transforming students into digital academics: a challenge at both the individual and the institutional level. BMC Medical Education, 15(1). http://doi.org/10.1186/s12909-0150330-5

Tinetti, M. E., Fried, T. R., \& Boyd, C. M. (2012). Designing Health Care for the Most Common Chronic Condition-Multimorbidity. JAMA, 307(23), 2493-2494. http://doi.org/10.1001/ jama.2012.5265

Uddannelses- og Forskningsministeriet. Bekendtgørelse om bachelor- og kandidatuddannelser ved universiteterne (uddannelsesbekendtgørelsen) (2013). Retrieved from www.retsinformation.dk/forms/r0710.aspx?id=160853 